\title{
No plant, no problem? Factoryless manufacturing, economic measurement and national manufacturing policies
}

Diane Coyle ${ }^{\mathrm{a}^{*}}$ and David Nguyen ${ }^{\mathrm{b}}$

'Factoryless manufacturing' describes the strategic decision by businesses to contract out part or all of their production, sometimes overseas. Although it has become widespread in some sectors of manufacturing, the phenomenon is not captured by existing economic statistics. This implies that the decline of manufacturing, often a focus of policy, may be overstated, while trade statistics fail to reflect globalized production. We present web-scraped evidence on the extent of factoryless manufacturing in the UK, finding that firms in sectors such as chemicals and pharmaceuticals are much more likely to use contract manufacturing, whereas in the US it is more prevalent within electronics. We also present case studies highlighting that firms can both use and provide contract manufacturing services. The limitations of the statistics imply that governments may believe their manufacturing sectors to be smaller than is the case and at the same time be unaware of the globalized character of much of that manufacturing production, adversely affecting their economic policies.

\author{
Keywords: factoryless manufacturing, contract manufacturing, economic \\ statistics, web-scraping \\ JEL Codes: D22, E01, L24, L60 \\ ${ }^{a}$ Bennett Institute for Public Policy, University of Cambridge, Cambridge, UK; ESCoE \\ *Corresponding author: Diane Coyle,dc700@cam.ac.uk
}

${ }^{\mathrm{b}} \mathrm{NIESR}$ and ESCoE 
Diane Coyle is Bennett Professor of Public Policy at the University of Cambridge, and a lead researcher at the Economic Statistics Centre of Excellence (ESCoE).

David Nguyen is a Senior Economist in the Trade, Investment \& Productivity directorate at NIESR, and a Research Associate at the Economic Statistics Centre of Excellence (ESCoE).

This research has been funded by the Office for National Statistics as part of the research programme of the Economic Statistics Centre of Excellence (ESCoE). 


\section{Introduction}

One of the dominant features of modern production is the extension of value chains and reorganisation of production activities into 'tasks' (Acemoglu and Autor 2011, Baldwin and Nicoud 2014, Timmer et al 2014). Firms increasingly operate as part of extended chains or networks, with the allocation of activity often determined by firm-specific capabilities (e.g. Pisano 2017, Teece et al 1997, Tassey 2014). International trade in tasks has been growing since the 1990s, driven by global value chains (GVCs) and the geographic fragmentation of production stages (Baldwin, 2006). Today around two thirds of global trade consist of intermediate inputs, while intangible inputs such as R\&D and IP account for 13\% (McKinsey Global Institute, 2019).

This reallocation poses challenges to measurement and the analysis of important dynamics in economic production, as statistics on flows within value chains are not collected, nor easy to collect (Houseman and Mandel, 2015; Ahmad, Moulton, Richardson and Van de Ven, 2018). Yet this information is vital for the understanding of growth and productivity dynamics, nations' or regions' comparative advantage, and even the relative role of manufacturing and services sectors. Misleading indications of the extent of decline in domestic manufacturing activity could have significant policy implications (Levinson 2017). As it stands, governments do not have the information that would enable them to make strategic decisions about the future of their economies, particularly as the covid-19 pandemic brings the prospect of a further reorganisation of supply chains. For example, a desire to boost the strength of domestic manufacturing without awareness of its current scope or its global production linkages may backfire, as some scholars argue has been the case with recent US tariff policies (Amiti et al 2019).

This paper focuses on a specific aspect of GVCs: factoryless manufacturing (FM), or in other words the use of contract manufacturing services such that the 
production of either intermediate products or entire product lines is outsourced to subcontractors, possibly located in another country. FM involves firms that design and innovate, retain intellectual property (IP), and also retail the products, but contract out (some of) the actual production. They are also referred to as 'factoryless goods producers' (FGPs). High profile examples include Apple, which does not manufacture hardware, Nike, which does not make shoes or clothing, and Dyson, which does not manufacture consumer white goods.

We explore the potentially significant implications of this phenomenon, as we find that the decline in manufacturing activity may be overstated in conventional statistics. For example, adoption of FM can result in businesses being classified outside of manufacturing into the distribution sector (Morikawa 2016). This needs to be seen against the backdrop of employment and output in 'manufacturing' declining by almost $40 \%$ in the UK in the last 20 years to only $9 \%$ of value-added and employment (McKinsey Global Institute, 2019). The use of contracted manufacturing services may also be contributing to this trend (Hauge \& O'Sullivan, 2019). In this paper, using a web scraping approach, we report the use of contract manufacturing across different sectors. We find that in the UK it is most widely used in the chemicals sector $(18 \%$ of the sample), as well as Life Sciences and Pharmaceuticals (18\%), which is different to the US where it is most prevalent in Electronics and Electronic Manufacturing (14\%), followed by Life Sciences and Pharmaceuticals (11\%).

Economic policies often place special weight on manufacturing. For example for the US, for instance, Levinson (2017: 9) states: "The national identity of manufactured production has been a matter of Congressional concern since at least the 1930s," and it remains at the centre of the 'Make America Great Again' approach; while for the UK, growth in 'advanced' manufacturing is at the centre of the latest Government Industrial 
Strategy (BEIS 2018). The statistical issue is therefore the manifestation of a deeper set of political economy issues. As Desrosieres (1993) demonstrated, statistics are artefacts of government that both measure and enable (see also Scott 1998 on the role of 'legibility', or orderly classification of subjects and domains, in structuring state action). They shape what the state knows and determine what it decides to do. National governments have long had a particular concern with national manufacturing capabilities. On the one hand, our findings support the possibility that the US and UK manufacturing sectors have declined less than the official statistics suggest, even as governments on both sides of the Atlantic are implementing policies intended to boost certain domestic manufacturing sectors. On the other hand, some authors have expressed concern that global production networks do lead to a permanent loss of domestic manufacturing capabilities, providing short term benefits for multinational firms at the expense of long term national economic productivity potential (Tassey 2014).

\section{The drivers of Factoryless Goods Production}

The use of contract manufacturing services is not a new phenomenon and has probably existed since the mass production era (see Figure 1). There are a number of reasons why companies outsource their manufacturing production, including saving on costs, producing close to final markets, and mitigating commercial risks associated with upfront fixed capital investments. It also allows them to focus on their core competences or capabilities, which could be higher value-added activities such as product development, design or marketing, and intangible assets (Penrose 1959; Quinn and Hilmer, 1994). FGPs tend to have higher levels of productivity and wages due to their focus on retaining in-house the high value-added stages of production (Bernard \& Fort, 2015; Morikawa, 2016). 
While some of these examples such as Apple and Nike have operated as FGPs for many years (Donaghu \& Barff 1990), the phenomenon has become more widespread since the 1990s. Timmer et al (2014) find that the foreign share of final value added in manufactures rose between 1995 and 2008 for $85 \%$ of the product categories in the World Input Output Database, indicating quite a pervasive phenomenon. UNCTAD (2011) estimated that by 2010 outsourced production had reached $\$ 1$ trillion in global revenues. The trend can be attributed to several factors, including the reduced costs of co-ordination enabled by digital technologies as well as other reduced trade frictions such as falling non-tariff and tariff barriers, and the access to opportunities for lower production costs particularly following China's WTO accession. The phenomenon of FGPs has thus expanded in recent decades in a process of continuing specialization driven by regulatory, organizational and technological change. Langlois (2003) emphasizes the evolution of transactions costs as the organisation of production catches up with the technologies of production. One of the recent enablers of this trend is digitalisation as it makes it easier to reallocate tasks within and among firms (Kamal, Moulton and Ribarsky, 2015; Baldwin, 2017). A related trend is the emergence of 'manufacturing on demand' websites based on large networks of approved manufacturers. These digital platforms promise to be faster and cheaper than alternative manufacturing options, while guaranteeing the quality of the final product. For example, at the time of writing xometry.com - a 'manufacturing-on-demand' website - provides instant quotes for 700,000 parts and claims to have access to 13 million machine hours through their network of 4,000 vetted manufacturing partners in the US. Another startup platform, fictiv.com provides similar services based on a network of $200+$ partners and has been described as the 'Airbnb of manufacturing'.

\footnotetext{
${ }^{1}$ Inc. Magazine; Salvador Rodriguez, $17^{\text {th }}$ Aug. 2016: https://www.inc.com/salvador-
} 
[Insert Figure 1 near here]

At the same time, there are costs involved in outsourcing production, arising from factors such as the requirement for specialised investments in some sectors or activities, reputational risks linked to environmental or labour standards for instance, and the role of tacit knowledge such that internal know-how is needed. The evidence of increasing contract manufacturing suggests these countervailing reasons have been outweighed by forces in the other direction since the 1990s. However, the trade-offs explain why a range of relationships between leading firms and their supply chains are observed, as the FGP tries to exercise control over the contractors (Strange and Humphrey 2019). For example, Dyson uses several contract manufacturers in South-East Asia to manufacture all of its electronic appliances. ${ }^{2}$ Sir James Dyson makes this claim for the relationship: 'We are not contracting out; we are heavily involved with the manufacturers and teaching them how to make each of our products as it comes out' ${ }^{3}$

In addition to the codifiability of information and absence or presence of information asymmetries - and thus the scope for monitoring and enforcement of standards or quality - market structure will play a part in the arrangements. If the leading company has significant market power, it will be able to exercise more control over its contracted manufacturers (Gereffi et al 2005). Maurer (2019) finds that certain oligopolistic market structures for the final products, and thus a lead firm with power to impose costs on suppliers, are more conducive to the ability to enforce high labour or

rodriguez/fictiv-is-the-airbnb-of-3d-printing.html

${ }^{2}$ For instance, Malaysia-based SKP Resources was awarded a 5-year contract worth $£ 550$ million to produce Dyson's upright vacuum cleaners, hand dryers and bladeless fans.

${ }^{3}$ The Edge Markets, $1{ }^{\text {st }}$ October 2018: http://www.theedgemarkets.com/article/dysontransforming-johors-highvalue-manufacturing-ecosystem 
environmental standards throughout the supply chain. For the anchor FGP firms in some sectors, contract manufacturing offers the best of both worlds: access to lower production costs combined with the ability to make their supply chain adhere to desired standards.

The use of FM affects the analysis of how production is organised and productivity dynamics. Manufacturing firms traditionally combined many nonmanufacturing activities in house, with many of their employees and revenues involved in areas such as sales and marketing. If the way FGPs combine inputs to produce output differs from the usual assumption of a linear chain of value added, this affects the measurement of value-added and productivity (Bernard \& Fort, 2017). Some authors consider that the process of industrial reorganisation is continuing with the evolution of 'distributed manufacturing', involving a production network of providers of various inputs into the process of producing a combination of goods and services to serve specific end-user needs (Srai et al. 2016). Firms focus on their strategic capabilities and operate a complex network of relationships in a production ecosystem. Contributory influences are the phenomena of additive manufacturing (enabling small scale and customised runs at dispersed locations) and the 'internet of things' as well as nowfamiliar outsourcing and offshoring choices (Bryson, Clark and Mulhall, 2013), all enabled by digital connectivity and processing. Manufacturing involves a cluster of related services, often technically specific, so the concept of the relevant sector needs to include these (Hauge \& O'Sullivan 2019). This type of production dynamic does not fit the idea of a linear value chain, allocating value added to specific stages in clearly defined sectors. It raises significant questions about economic policy frameworks that give priority to manufacturing sectors on the basis of presumptions about productivity based on the conventional linear analysis. 
However, understanding factoryless manufacturing (and related forms of international production arrangements such as merchanting, toll processing and subcontracting UNECE, 2015) is severely hampered by the lack of availability of data on international production arrangements. Therefore we next consider definitions of factoryless manufacturing and survey some previous attempts to measure its scope.

\section{Defining factoryless manufacturing}

There are several overlapping definitions of factoryless manufacturing (FM) and attempts to measure it. FM can be considered in a sense the most 'extreme' arrangement as the entire production process transforming materials and intermediate goods into final goods is carried out by other firms, while the FGP retains the IP and the relationship with customers. The definitions vary according to the activities undertaken by the FGP and contract manufacturers respectively, and according to the ownership of material inputs to production.

For example, in one of the earliest definitions of FM, the Economic Classification Policy Committee (ECPC, 2010: p.3-4) of the US Office of Management and Budget $(\mathrm{OMB})$ considered a production arrangement as factoryless manufacturing if a business:

'Outsources all of the transformation steps that traditionally have been considered manufacturing, but undertakes all of the entrepreneurial steps and arranges for all required capital, labour, and material inputs required to make a good.'

By relating to relatively broad concepts such as entrepreneurship and 'traditional manufacturing' this definition is fairly broad. But it included the requirement for FGPs to own the material inputs to production, consistent with the System of National Accounts (SNA 2008) and the Balance of Payments and International Investment 
Position Manual (BPM6). Kamal, Moulton and Ribarsky (2015) followed the OMB definition but concluded that the 'ownership of material inputs' was not a practical indicator for classification purposes. The UNECE Guide to Measuring Global Production (UNECE, 2015: p.14) places the focus on the provision by FGPs of intangible inputs, while the sourcing of raw materials as well as labour and machinery is left with the contract manufacturer. Bayard et al (2015) also emphasise ownership of IP. Further variations of these definitions can be found in a number of subsequent academic studies. For example, Bernard and Fort (2015, p.518) define a factoryless manufacturer as a business that:

'Has no manufacturing establishments in the United States, but performs preproduction activities such as design and engineering itself and is involved in production activities, either directly or through purchases of contract manufacturing services (CMS) ${ }^{\prime}$

Similarly, Morikawa (2016: p.11) analyses FGPs in Japan uses the definition:

'Firms satisfying all of the following three criteria: (1) they have no sales from the firms' own manufacturing activity, (2) they have no domestic subsidiaries classified as manufacturing, and (3) they outsource the manufacturing process to other (domestic or overseas) firms.'

This definition is useful in that the ownership of actual production plants is fairly straightforward to measure in business surveys, but a firm might still own some plants in its home country, not outsourcing all their production to contract manufacturers.

Table 1 summarises the characteristics varying between previous definitions of FGPs. For the purposes of policy analysis, we consider ownership and control of 
intangible assets, but not material inputs, to be essential, along with the use of contract manufacturing for some production but not necessarily all.

\section{[Insert Table 1 near here]}

\section{Measuring factoryless manufacturing}

FM can pose measurement challenges for the measurement of national income, productivity, industrial production, international trade, employment, wages, profits, and producer price indices, as well as sector classification (Doherty, 2015). Unfortunately, existing empirical evidence concerning the scale of FGPs' activity is limited. Two particular issues stand out: sector classification, and international trade statistics. As noted, even reallocating FGPs to the manufacturing sector to get closer to measuring the 'true' sectoral composition of the economy could be significant considering the political attention the 'shrinking' manufacturing sector has received in Western countries in recent years. $^{4}$

In the UK, some indication of the likely scale of FM in comes from Office for National Statistics (ONS) estimates that in 2016 around $6.7 \%$ of the UK's total service sector revenues came from production activities. ${ }^{5}$ Further, around two thirds of those were generated by businesses operating in wholesale and retail trade, the precise sectors that were found to make heavy use of contract manufacturing in the US. The question is what products firms in these service sectors are actually producing, and whether some

\footnotetext{
${ }^{4}$ The 'hybridisation of services and manufacturing' (Bryson, Clark \& Mulhall, 2013) also means that a growing number of manufacturing firms are generating revenues by selling services. For example, Crozet and Milet (2017) find that $12 \%$ of manufacturing firms in France do not sell any products at all. However, they do not discuss whether some of these firms could be contract manufacturers.

${ }^{5}$ Preliminary estimates: https://www.ons.gov.uk/businessindustryandtrade/business/businessservices/datasets/annuals urveyofgoodsandservicesindustrybyproductmatrix
} 
of them should be reclassified to manufacturing (e.g. if production makes up the bulk of their revenues). As approximately $15 \mathrm{~m}$ people work in the private service sector, if the $6.7 \%$ proportion is taken as a guideline up to $1 \mathrm{~m}$ could potentially be reclassified compared with about $3 \mathrm{~m}$ formally categorised as employed in manufacturing. This is a very rough and ready figure but serves to illustrate the importance of the phenomenon, in the context of the political salience of manufacturing industry.

In the US Bernard and Fort $(2013,2017)$ found that reclassifying FGPs could shift between 0.4 to 1.9 million workers from wholesale trade to manufacturing, in other words $3-14 \%$ of total manufacturing employment in $2007 .{ }^{6} \mathrm{FM}$ also seems to be an important production model in sectors including pharmaceuticals, apparel, toys and games, electronic components, and ICT equipment (Bayard, Byrne and Smith, 2015). In addition, their analysis of company reports revealed that in 2012 around $46 \%$ of S\&P 500 firms reported the use of some contract manufacturing (up from $30 \%$ in 2002). More importantly, 20\% of these firms exclusively relied on FM for their production, compared to $16 \%$ in 2002 . There are also some estimates for Japan. Morikawa (2016) found that in 2013 around $18.4 \%$ of the surveyed Japanese firms classified as not in manufacturing could be classified as FGPs, and 3.1\% as offshoring-FGPs. The former figure fell from $19.7 \%$ in 2009 while the latter increased from $2.4 \%$ over the same period. These studies are summarised in Table 2.

[Insert Table 2 near here]

\footnotetext{
${ }^{6}$ The study is based on the Census of Wholesale Trade for 2002 and 2007.
} 
The standard NAICS or SIC sector classifications are anyway not invariant to the value chains operating in different sectors of the economy. For example, 'construction' (Section F of SIC) excludes architecture and engineering (M71), and project management, which are high value-added activities but not vertically integrated; and includes relatively low value-added maintenance and repair. On the other hand, 'motor vehicle manufacture' (C29) includes the high value-added design and engineering phases, which are vertically integrated by the major manufacturers, but excludes lower value-added repair and maintenance (G45) (Winch, 2003). Without doubt, business model choices as to which part of the value chain to occupy will cut across conventional sector definitions (see Figure 2).

[Insert Figure 2 near here]

The trade measurement issues are even thornier. Under current accounting standards FM is in principle treated as if it were merchanting, meaning the FGP (i.e. the principal) is performing service activities while the foreign contract manufacturer is engaged in production (UNECE, 2015). However, factoryless manufacturing can impact statistics for total exports and imports as well as the sectoral composition of trade flows (Doherty, 2015). The totals can be distorted if certain flows are not captured in current business surveys conducted by national statistical institutes. The composition changes if FGPs (at home or abroad) are classified differently than in the past. Figure 3 presents a schematic representation of this, highlighting how specific flows may be measured in practice. 
It is not clear how in practice different national statistical institutes are recording this phenomenon - if at all. However, the implications are clearly profound. For example, if Dyson is producing a vacuum cleaner in Malaysia and then sells it in Japan, we cannot be sure whether this is recorded as a UK goods export. ${ }^{7}$ The reverse holds if a contract manufacturer based in the UK is producing for a foreign FGP using that principal's intellectual property.

\section{Factoryless manufacturing in key industries}

\section{Pharmaceuticals}

The use of contract manufacturers (CMs) plays an important role in pharmaceuticals. According to a study by market research firm ISR (2016), around two thirds of total production is outsourced, while a quarter of pharmaceutical companies outsource all of their production. ${ }^{8}$ Some activities are more likely to be outsourced, including those using emerging technologies (which are higher risk), specialised technologies (which are only needed occasionally), or mature technologies (which are widely-available and of lower strategic importance). ${ }^{9}$ On the other hand, products that involve core technologies that are of high strategic importance are more likely to be kept in-house.

Bernard and Fort (2015) find that factoryless manufacturing is more likely to occur in the pharmaceutical industry (accounting for $24 \%$ of total US FGPs in the wholesale sector in 2007). They describe pharmaceuticals (along with production of apparel) as a 'typical' industry where the location of design or R\&D is detached from

\footnotetext{
${ }^{7}$ Similarly, how is the sale of a Jaguar E-PACE recorded when it is produced by a Canadianowned plant in Austria but then sold across the border in Germany?

${ }^{8}$ The report is based on a web-based survey of 101 companies mainly from North America and Europe that are all involved in outsourced manufacturing.

${ }^{9} \mathrm{Jim}$ Miller, “What's Next for the CMO Industry?", http://www.pharmsource.com/whats-nextfor-the-cmo-industry-2/
} 
the location of production. Similarly, Bayard, Byrne and Smith (2015) show that around $70 \%$ of US pharmaceutical companies in 2012 used some contract manufacturing (up from $48 \%$ in 2002).

The UK has a significant pharmaceutical industry. ${ }^{10}$ We searched all available annual reports of pharmaceutical companies listed on the London Stock Exchange in 2019 for the use of 'contract manufacturing services'. ${ }^{11}$ We found in the reports a number of explanations for why pharmaceutical companies would use contract manufacturing, including: avoiding risky capital investment (e.g. if a product fails in late phases of clinical research), having flexibility when future demand is uncertain, achieving cost savings as $\mathrm{CM}$ suppliers can specialise, and improving the ability to focus on their own strategic goals and R\&D. Many of the listed companies both produce their own-brand products and at the same time act as CMs for other companies.

For example, GlaxoSmithKline (GSK), one of the market leaders in the production of pharmaceuticals, vaccines, and other consumer healthcare products, is a prominent user and supplier of contract manufacturing services. ${ }^{12}$ On its website it lists capabilities in contract manufacturing within the areas of antibiotics, inhalation, foams, liquids and active pharmaceutical ingredients. The company also reports its use of contract manufacturers for a wide range of products, ${ }^{13}$ and highlights the importance of

${ }^{10}$ According to the ONS, the pharmaceutical sector had a gross value added of $£ 13$ billion in 2017 (7\% of all manufacturing), https://www.ons.gov.uk/economy/grossvalueaddedgva

${ }^{11}$ More specifically, we searched for the terms "contract manufact", "third party", "outsourc", and "subcontract". This is because companies may use different terminology to refer to the same phenomenon. To avoid confusion, we provide direct quotation from the Annual Reports and websites where appropriate. Our approach is similar to the one adopted by Bayard, Byrne \& Smith (2015). We also considered other pharmaceutical companies that have significant presence in the UK.

${ }^{12}$ In 2017 the group employed 98,481 people and generated combined revenues of $£ 30.2$ billion with operating profits of $£ 4.1$ billion.

13 'We rely on materials and services provided by third party suppliers to make our products, including active pharmaceutical ingredients (API), antigens, intermediates, commodities, 
regular auditing and quality assurance to reduce associated risks. ${ }^{14}$ It recently announced a strategic decision to reduce the number of subcontracted CMs by a quarter to reduce its supply chain complexity. ${ }^{15}$

One of the market leading CMs in the sector is BioXcellence, which is the contract manufacturing business of the Germany-based Boehringer Ingelheim. ${ }^{16}$ The $\mathrm{CM}$ subsidiary is run independently and produces for a number of pharmaceutical companies, including 15 of the top 20 pharmaceutical companies globally, using plants in Austria, China, Germany and the US. ${ }^{17}$ While Boehringer Ingelheim has offered contract manufacturing services for more than 25 years, BioXcellence is a brand that was launched only in 2012 specifically to market contract manufacturing capabilities. In 2017 the parent company reported total sales of $€ 678$ million in biopharmaceuticals under contract manufacturing arrangements, more than $50 \%$ up from $€ 449$ million in 2013 (see Boehringer Ingelheim annual reports). Like GSK, Boehringer Ingelheim is itself also a buyer of contract manufacturing services.

Headquartered in Hertfordshire, Consort Medical is a 'Contract Development and Manufacturing Organisation (CDMO)' that serves pharmaceutical companies with drug and device development, formulation and manufacturing. ${ }^{18}$ It manufactures

and components for the manufacture and packaging of Pharmaceutical, Vaccine and Consumer Healthcare products.' - GSK, Annual Report 2017

14 'Contract manufacturers making our products are expected to comply with GSK standards and are regularly audited to provide assurance that standards are met.' - GSK, Annual Report 2017

15 'Since 2015, we have streamlined the number of contract manufacturers (CMOs) we use by $24 \%$ to reduce complexity in our supply chain' - GSK, Annual Report 2017

${ }^{16}$ In 2018 the group employed around 50,000 people and generated combined revenues of 17.5 billion with operating profits of 2 billion.

${ }^{17}$ Advertised as 'Your product - Our passion' on the company website, which further states that 'We have helped our customers bring 31 commercial biopharmaceuticals to the market, with three of these products ranking among the world's Top 20 best-selling biotech products.' https://www.bioxcellence.com/about-us/our-track-record

${ }^{18}$ Consort Medical is listed on the London Stock Exchange and split into two divisions: Bespak and Aesica. The group's revenues reached $£ 311$ million in 2017, with profits of $£ 42.7$ 
products both as a contract manufacturer, as well as using its own intellectual property. ${ }^{19}$ On its website Consort describes itself as a 'leading' contract manufacturer with 'significant experience'. In its 2016 annual report the company states: 'The global pharmaceutical contract manufacturing market was estimated to be valued at US\$58bn in 2014 and is forecast to reach US\$84bn in 2020.'

Dechra Pharmaceuticals is a UK-based supplier as well as buyer of contract manufacturing services. ${ }^{20}$ Between 2005 and 2015 the company's revenues from contract manufacturing increased from $£ 6$ to almost $£ 20$ million. However, in 2017 they declined to $£ 17$ million, in line with the company’s long-term strategy to move away from third party manufacturing to focus on producing its own brands.

Another provider of contract manufacturing services is the UK-based Hikma Pharmaceuticals. Its clients include Boehringer Ingelheim, which is also a major stakeholder in Hikma. However, according to Hikma's 2017 annual report, a significant reduction in orders from Boehringer reduced its revenues. ${ }^{21}$

The British-Swedish multinational AstraZeneca reports that the production of some of its intermediate inputs is outsourced to third party providers, including most the Active Pharmaceutical Ingredient (API) manufacturing, formulation and packaging. ${ }^{22}$ However, the company retains the final stages of production in-house to have full control of product integrity and quality.

Similarly, BTG - a producer of medicine products and pharmaceuticals outsources the production of key intermediate products to third party suppliers. The

million. Bespak focusses on drug delivery devices (e.g. inhalers or auto-injectors), while Aesica provides active pharmaceutical ingredients (APIs) and other drugs.

19 '[our product development includes] both contract manufacturing and products with our own proprietary intellectual property (IP)' - Annual Report 2017

20 'We provide contract manufacturing services to other pharmaceutical companies' - Dechra Pharmaceuticals plc, Annual Report 2012.

${ }^{21}$ Hikma plc Annual Reports: https://www.hikma.com/investors/hikma-annual-report/

${ }^{22}$ Based on company Annual Reports 2015, 2016, 2017. 
company also licenses its intellectual property rights to third party companies to develop and sell products.

Another large buyer and supplier of contract manufacturing services is Shire, which specialises in treatments for rare diseases. ${ }^{23}$ The company is listed in London but headquartered in the US. It reports that in 2017 it paid almost $\$ 460$ million for contract manufacturing services, compared to $\$ 325$ million in 2015. Following the acquisition of Baxalta in 2016, Shire also became a provider of CMS and reported almost $\$ 100$ million in sales related to contract manufacturing.

Finally, SkyePharma, which is part of the British Vectura Group, offers manufacturing services from development, production and packaging. It operates its main plant in Lyons, France.

Companies that did not describe the purchase or provision of $\mathrm{CM}$ in their most recent annual reports include Midatech Pharma, Oxford BioMedica, Worldwide Healthcare Trust plc, and Smith \& Nephew. However, this does not necessarily mean that they are not engaged in such production arrangements as they are not required to report them and/or might use different terminology to describe them. ${ }^{24}$

\section{Automotive}

Auto production is another sector where use of contract manufacturing is reasonably widespread. One of the leading contract manufacturers in the automotive industry is the Canadian firm Magna International, which can produce entire vehicles with internal combustion, hybrid or fully electric engines. For example, since 1979, Magna has

23 'Shire conducts its own manufacturing operations for certain of its products and is reliant on third-party contract manufacturers to manufacture other products and to provide goods and services.' - Shire Annual Report 2016

${ }^{24} \mathrm{We}$ tried to mitigate this risk by searching broadly and reading around relevant sections of the companies' annual reports. 
produced more than 300,000 units of the Mercedes-Benz G-Class using a dedicated workforce in its contract manufacturing facility in Graz. ${ }^{25}$ In addition, it produces some models within BMW's 5 Series as well as Jaguar's I-PACE and E-PACE vehicles. ${ }^{26}$ In July 2017, Jaguar Land Rover announced that:

'From late 2017, the Jaguar E-PACE will be the first vehicle to be produced as part of Jaguar Land Rover's contract manufacturing agreement with Magna Steyr, an operating unit of Magna Inc, in Austria. It will be joined by the all-electric Jaguar IPACE from 2018. ${ }^{27}$

However, the news release goes on to highlight that the car was 'designed and engineered' in the UK, and the main reason for using the contract manufacturing arrangement is the fact that its UK plants are at operational capacity. Some sources estimate global sales of the E-Pace to be close to 28,000 in $2018 .^{28}$ However of these around 2,200 were sold to Chinese customers who are supplied by the Jaguar Land Rover factory in Changshu. ${ }^{29}$ Sales from the I-Pace model added another 6,500 vehicles likely to be entirely produced by Magna Steyr in $2018 .^{30}$

According to company accounts, Magna Steyr produced 144,500 complete vehicles in 2018 , which represents a significant increase compared to 77,900 in the year before and 75,000 in $2016 . .^{31}$ For 2019 Magna expected to generate around $\$ 7$ billion from selling complete vehicles, amounting to around $17 \%$ of its total revenues. ${ }^{32}$ This

\footnotetext{
${ }^{25} \mathrm{https} / /$ www.magna.com/insights/article/a-legendary-team-for-a-legendary-vehicle

${ }^{26} \mathrm{https}: / / \mathrm{www} . \mathrm{magna.com} /$ insights/article/building-a-unique-reputation

${ }^{27}$ https://media.jaguarlandrover.com/news/2017/07/jaguar-e-pace-built-two-continents-satisfycustomer-demand

${ }^{28} \mathrm{http}: / /$ carsalesbase.com/european-car-sales-data/jaguar/jaguar-e-pace/

${ }^{29} \mathrm{http} / / /$ carsalesbase.com/china-car-sales-data/jaguar/jaguar-e-pace/

${ }_{30} \mathrm{http://carsalesbase.com/european-car-sales-data/jaguar/jaguar-i-pace/}$

$31 \mathrm{https://www.magna.com/company/investors/financial-reports-public-filings/quarterly}$

32 https://www.magna.com/company/newsroom/releases/release/2019/02/22/press-release--magna-announces-fourth-quarter-and-2018-results-and-raises-quarterly-cash-dividend-by$\underline{11-}$
} 
figure is remarkable considering that sales of complete vehicles contributed only around \$2.94 billion (or 7.5\%) to the company’s total revenues in 2017 and $\$ 2.2$ billion in $2016 . .^{33}$

Overall, Bayard, Byrne and Smith (2015) estimate that around 22\% of transport equipment manufacturers within the S\&P500 were using a factoryless manufacturing model. What seems clear is that these vehicles are exclusively produced for a specific client and the provider of the contract manufacturing service is not able to market or sell them on his own. They also do not control the design and R\&D process or own the intellectual property. However, it is not immediately clear where the creation of economic value is recorded in the statistics and when ownership of the final product changes (from Magna to Jaguar or Mercedes-Benz). In 2017 total annual production of the Mercedes G-Class reached $22,000,{ }^{34}$ of which only 4,157 were newly registered in Germany $^{35}$ and 62 in Austria. ${ }^{36}$ This means that a Canadian-owned plant in Austria is producing a complete vehicle for a German-owned company selling the vast majority of the model outside both its home market and the country where it was produced. ${ }^{37}$ It is unclear where ownership is transferred and whether we are dealing with goods or service exports or imports.

In a further example, the Chinese electric vehicle start-up NIO shelved its initial plan to build its own vehicle factory in Shanghai. Instead it will continue to use its

\footnotetext{
${ }^{33}$ Magna Annual Report 2017: https:/www.magna.com/company/investors/financial-reportspublic-filings

${ }^{34}$ https://www.automobil-produktion.de/hersteller/neue-modelle/magna-steyer-startetproduktion-der-neuen-mercedes-g-klasse-124.html

${ }^{35}$ https://de.wikipedia.org/wiki/Liste der Neuzulassungen von Personenkraftwagen in Deutsc hland nach Segmenten und Modellreihen

36 https://gelaendewagen.at/artikel19/suv zulassungen_2018 03.php

37 4,188 were sold in the US and 635 in Canada. https:/canada.autonews.com/article/20180129/CANADA01/301299998/mercedes-benz-gclass-poised-to-sell-out-in-canada-automaker-says
} 
current contract manufacturer, JAC Motors. ${ }^{38}$ NIO, which is listed on the New York Stock Exchange, reported total production of 12,775 vehicles via JAC Motors in $2018 .{ }^{39}$ On the company website NIO describes its business model as: 'We design, jointly manufacture, and sell smart and connected premium electric vehicles.' Though it is headquartered in Shanghai it operates a design headquarters in Munich with 100 employees and global software development is operated out of its San Jose, California office with 520 employees. ${ }^{40}$

Three current trends in the auto sector are likely to increase the reliance on contract manufacturers to produce complete vehicles: electrification, digitalisation and artificial intelligence (i.e. self-driving capabilities). The production of electric vehicles is less complex and involves fewer moving components, enabling further outsourcing because production and quality control is easier. ${ }^{41}$ At the same time, digitalisation means that the value-added in vehicles is increasingly coming from software development and data services, meaning that the actual physical production is of relatively less strategic importance to the firm. Hence there is diminishing concern over knowledge-outflows related to outsourcing of production. Finally, advances in artificial intelligence and the development of self-driving systems has attracted a large range of tech companies (e.g. Google, Uber, Baidu, Didi Chuxing, Lyft, Tencent, Apple), and

${ }^{38}$ NIO Inc. press release, $5^{\text {th }}$ March 2019: https://ir.nio.com/news-events/news-releases/newsrelease-details/nio-inc-reports-unaudited-fourth-quarter-and-full

${ }^{39}$ NIA Inc. SEC 6-k form, $6^{\text {th }}$ March 2019: https://ir.nio.com/static-files/a73c4fd2-bbe3-45e29834-39c7c2edfa70

${ }^{40}$ NIO website, accessed $7^{\text {th }}$ March 2019: https://www.nio.io/about

41 'Battery-powered EVs have only 20 to 30 moving parts in their drivetrains, compared to 130 to 170 moving parts in an internal combustion engine' (Mc Kinsey Global Institute, 2019: page 82 ).

https://www.mckinsey.com/ /media/McKinsey/Featured\%20Insights/Innovation/Globalizati on $\% 20$ in $\% 20$ transition $\% 20$ The $\% 20$ future $\% 20$ of $\% 20$ trade $\% 20$ and $\% 20$ value $\% 20$ chains/MGI -Globalization\%20in\%20transition-The-future-of-trade-and-value-chains-Full-report.ashx 
spin-offs or start-ups (e.g. Aptiv, Zoox, Oxbotica) that might not have any production capabilities but instead rely on third-party CMs.

\section{New measures of UK and US contract manufacturing}

Given the paucity of data on the use of contract manufacturing arrangements, we scraped information from company websites in the UK and US. We used a machinelearning web crawler developed by Glass.ai to look for specific themes that companies in the UK and US describe on their websites. ${ }^{42}$ This is similar to the approach adopted by Bayard, Byrne and Smith (2015), who manually searched the annual reports of companies in the S\&P 500. However, their study was restricted to the largest companies in the US classified as being in the manufacturing sector. We looked at the entire universe of UK and US businesses with a website, regardless of their size or sector classification.

However, our method does have limitations. First, we are unable to capture businesses without a website, although it is likely that all businesses we are interested in will have one.

Secondly, we are not able to capture firms that do not disclose their production model on their website, so our figures may understate the scope of contract manufacturing. Nevertheless, the intelligent crawler can partially overcome this issue as it is not tied to specific keywords but can read text at large scale in an unsupervised way. It is also largely representative for the UK economy, as comparisons of Glass.ai

\footnotetext{
42 Description from Glass.ai website (January 2019): 'Glass is an automated web research capability for Market, Economic and Social Research. Artificial Intelligence and Natural Language Processing techniques have been created to build an intelligent web crawler that reads the web, recognising sites that have the characteristics of commercial, non-profit or governmental organizations. These characteristics include finding a description of the business or activity, identifying the people mentioned on the site - which may also include roles and biographies - and extracting the postal addresses referenced. Other information is captured around news content and job listings to form a picture of each organization.'
} 
data with official business registers have shown (Bishop and Mateos-Garcia, 2019). Further, in the previous section we presented some findings based on reading annual reports of UK businesses operating in the pharmaceutical and automotive sectors, which provide a cross-check.

Thirdly, we are not able to distinguish between buyers and sellers of contract manufacturing services. However, a manually check of a random sub-sample of the results confirmed that most businesses referring to it are providers rather than users of CM. This is intuitive, as a business that is selling products that were not produced inhouse (e.g. Mercedes G-Class, Jaguar F-Pace), would not necessarily mention it on its website for strategic or marketing reasons.

For our text-based analysis the Glass.ai algorithm searched for the number of businesses that have activities based on contract manufacturing. Crucially, the intelligent crawler is not restricted to specific terms but can 'understand' what a company is doing even though it might not use the exact term 'contract manufacturing'. ${ }^{43}$ The choice of terms is based on the findings from the above case studies of the pharmaceutical and automotive sectors. In our case it listed businesses classified within the following keywords:

- Contract Manufacturer

- Contract Manufacturing Services

- Contract Manufacturing Organization

Overall, we identified 491 organisations in the UK and 2,534 in the US in this way. Further, we break those down by sector as presented in Tables 3 and 4, for the UK

\footnotetext{
${ }^{43}$ Using Natural Language Processing (NLP) the algorithm can understand text at scale, identifying 'business description' on websites, e.g. in the 'About' section. The machinelearning model to assign the sector to a company was initially trained on a sector classification taken from Linkedin.
} 
and the US respectively. Here it is important to mention that the Glass.ai crawler uses a sectoral classification based on natural language processing and artificial intelligence to classify a business into around 100 sectors. Hence, these may not correspond to the firms' formal NAICS or SIC industrial classifications. To check the quality of our results we manually read key sections of 25 randomly selected websites in the UK and found that at least 21 were actual sellers of contract manufacturing services. Details of manual searches by company are provided in Appendix B.

For the UK (see Table 3 ) around $18 \%$ of businesses with activities in contract manufacturing were classified as operating in the 'Life Sciences \& Pharmaceuticals' sector, closely followed by 'Chemicals' (17\%), 'Biotechnology' (15\%) and 'Electrical and Electronic Manufacturing' (13\%). Around 10\% were classified within 'Mechanical \& Industrial Engineering', 8\% in 'Medical Devices'. 'Cosmetics \& Toiletries', 'Machinery' and 'Textiles' each had around 3\% of businesses active in CM. This is a striking finding since the top 5 sectors when searching for businesses in the UK without keywords are: Construction (5\%), Hospitality \& Restaurants (4\%), Charities \& Foundations (4\%), Automotive (4\%), and Health, Wellness and Fitness (3\%).

In the US (see Table 4), the sectors with the highest share of businesses active in contract manufacturing were in 'Electrical \& Electronic Manufacturing' (14\%) and 'Life Sciences \& Pharmaceuticals' (11\%), followed by 'Plastics' (10\%) and 'Medical Devices' (9\%), 'Chemicals' (8\%), and 'Machinery' and 'Semiconductors \& Electronic Systems' (both 7\%). The share for 'Mechanical \& Industrial Engineering' and 'Biotechnology' is around 6\% each. Again, we are given confidence in our results by the fact that these shares are very different to the overall sectoral decomposition of Glass.ai data. When searching without keywords, most organisations are classified as 'Charities \& Foundations' (5\%), followed by 'Hospitals and Medical Practices' (4\%), 
'Real Estate and Property Management' (4\%), 'Hospitality \& Restaurants' (4\%) and 'Construction' (4\%).

Our findings are similar to those of Bayard et al. (2015) for the US who report that around the majority of contract manufacturers are classified within 'Electrical equipment' and 'Computer and communication equipment' (together 11\%), followed by 'Machinery' (11\%), 'Pharmaceuticals and Medicine' (9\%), 'Chemicals' (8\%) and 'Medical Devices' (6\%). The largest difference between our results and theirs can be found in the 'Food \& Beverages' sector, as we find only 1\% of US companies with contract manufacturing activities, while they reported a figure of $14 \%$. Some of these are due to the difference in methods since they are only looking at the annual reports of the largest US companies and used a precise keyword search.

[Insert Table 3 near here]

[Insert Table 4 near here]

It is noteworthy that these sectors are all high value added and export-intensive production sectors, in each case. The prevalence of FGPs across sectors likely reflects the greater likelihood of leading companies in each country's respective high-valued added sectors to be able to take advantage of the benefits of contract manufacturing production arrangements while being able to exercise adequate governance over these complex ecosystems. The case studies above indicate the kinds of strategic choices being made.

We consider this web-scraping of text applying Natural Language Processing (NLP) offers a promising approach to understanding the FM phenomenon. The methodology using Glass.ai technology has also been applied in the context of 
measuring the scope of the UK's immersive technology sector (Mateos-Garcia et al 2018). Kinne and Lenz (2019) developed their own neural network classification model to identify innovative firms in Germany on the basis of their website text. One possible extension of the results we report here would be to develop a predictive model for survey responses concerning variables such as employment and turnover, validating them where possible with Companies House data, as in Mateos-Garcia et al (2018). However, this is a far larger task than their exercise for a specialist sector, and it would be preferable to record the FM phenomenon through the official business surveys. A further extension would be to consider the implications of FM for trade statistics and the mapping of international production relationships through web-scraping and NLP. The next section briefly discusses the evidence available from existing trade statistics.

\section{Evidence from existing official trade data in the UK}

The US business surveys have introduced occasional relevant questions (Bernard and Fort, 2015), ${ }^{44}$ and according to Doherty (2015), the import of contract manufacturing services is currently quite likely to be recorded as a resale of products (i.e. merchanting). As a result, sectors with relatively high resale figures will likely capture some activity of FGPs.

To explore this in the case of the UK we looked at selected products reported in the International Trade in Services Survey (ITIS) which the ONS conducts on an annual basis (see Table 5). ${ }^{45}$ However, we have to be cautious in interpreting those figures,

\footnotetext{
${ }^{44}$ A list of questions from US surveys has been included in Appendix C.

${ }^{45}$ The ITIS survey has been revised in 2013 to comply with international standards and a question on 'manufacturing services' was added. One caveat is that the survey excludes travel, transport and banking industries. A copy of the full questionnaire can be found via: https://www.ons.gov.uk/economy/nationalaccounts/balanceofpayments/methodologies/intern ationaltradeinservicesitis
} 
since it is not clear how businesses actually interpret the survey and whether they report the use of contract manufacturing at all.

Merchanting: On the exports side, businesses are asked to report 'Total sales during the reporting period of goods purchased for resale that have remained outside the UK.' In 2018 this amounted to $£ 10.3$ billion, which is almost three times as high as in 2013 (ONS, 2020), ${ }^{46}$ while businesses in the wholesale \& retail industry accounted for $63 \%$ of those. On the import side the ONS asks for 'Total goods purchased for resale during the reporting period that have remained outside the UK,' with businesses reporting a total of only $£ 401$ million, down from $£ 440$ million in 2013.

[Insert Table 5 near here]

Manufacturing services: In addition to merchanting activities of UK business, ITIS asks about 'Manufacturing services on goods owned by others,' which on the import side is defined as 'fees charged by foreign businesses for the processing, assembly, labelling and packing of goods overseas that are owned by your business.' In 2018 total imports of manufacturing services reached $£ 1.26$ billion, up from $£ 730$ million in 2013, with around a third of the total reported by businesses in the wholesale $\&$ retail industry.

Charges for intellectual property (IP): As discussed above, the use of contract manufacturing services overseas by a UK company should theoretically be recorded as a UK export of research and development services. One question in ITIS comes close to this definition by asking businesses to report 'Charges or payments for the use of Patents and other intellectual property that are the end result of research and development without transfer of ownership.' In 2018 UK businesses exported a total of

\footnotetext{
${ }^{46}$ ONS dataset: International Trade in Services Survey, January 2020. https://www.ons.gov.uk/businessindustryandtrade/internationaltrade/datasets/internationaltra deinservicesreferencetables
} 
$£ 2.8$ billion under this category, up from $£ 1.5$ billion in $2013 .{ }^{47}$ However, the Wholesale \& Retail industry officially recorded almost none, which, given the scale of contract manufacturing in the sector, strongly suggests that there is under-reporting. It may be that respondents do not interpret some of their intellectual property in those terms.

By looking at current business surveys conducted by ONS we can thus identify a number of categories that are potentially related to factoryless manufacturing by UK businesses. However, the existing business trade surveys do not capture the information needed to inform effective policy with respect to manufacturing and supply chains.

\section{Summary}

It is clear there are a number of challenges related to the measurement and analysis of factoryless manufacturing. This paper has provided novel evidence concerning the prevalence of factoryless manufacturing. In the UK the phenomenon is most widespread among businesses in the chemical and pharmaceutical sector, biotech, and electronics. In the US, on the other hand, it is mainly found in electronics, pharmaceuticals, plastics and medical devices. It is possible that the actual proportions may be higher if companies opt not to describe their production arrangements on their websites for strategic reasons. The case studies revealed that firms are operating production models that mix in-house production with contract manufacturing, for some products (as in the auto sector examples) or for some intermediate inputs. Companies can be buyers and suppliers of contract manufacturing services at the same time (as in the pharma examples).

\footnotetext{
${ }^{47}$ This figure is also high compared to 'outright sale of IP' which only accounted for $£ 188$ million.
} 
This complicates clear-cut attribution of revenues - or firms - to 'services' and 'manufacturing'. Furthermore, firms may own production facilities in various countries that might provide and/or purchase contract manufacturing services. This highlights the complexity of within-company transfers of intellectual property, making attribution of value added by country even more challenging. The increasing importance of intangible inputs in manufacturing, and the transfers between FGPs and CMs, makes it difficult to track cross-border flows of intellectual property needed for the production of high and medium-high technology products.

It is important to start collecting relevant statistics if the dynamics of production in modern economies are to be understood, and economic policies are to be appropriately designed and targeted. However, better surveys and collection of statistics do not address the underlying issue of the inability of the existing statistical framework or categories to reflect the reality of how many businesses have increasingly organised their activities, focusing on core capabilities and reorganising tasks internally and in their wider global production network. The increasing inadequacy of the economic statistics in light of globalization has been pointed out in other contexts (eg Linsi and Muegge 2019). The broader challenge is that the existing statistical framework was established for nationally-based firms and economies, with relatively few intangible inputs and outputs, producing in clearly defined linear value chains corresponding to sectors. The categorisations do not fit a world of global production networks, involving significant intangibles and services, and organised around tasks.

The fate of globalisation is highly uncertain in the current conjuncture, which combines major global problems such as environmental threats and the covid-19 pandemic with rising nationalist forces including identity politics and populism (Mann 1997, Pabst 2019). We have shown in this paper that the growing phenomenon of factoryless manufacturing since the 1990s is almost completely invisible in official statistics. As it stands, governments do not have the statistical knowledge that would enable them to implement well-informed economic policies with regard to production in key sectors. Without this information, governments will neither be able to track any re-formation of 
supply chains in response to the pandemic nor be able to deliver on the common aim of supporting strong domestic manufacturing capability. 


\section{References}

Acemoglu, D. \& Autor, D. (2011). 'Skills, Tasks and Technologies: Implications for Employment and Earnings', Chapter 12 in David Card, Orley Ashenfelter, (Eds.), Handbook of Labor Economics (Volume 4, Part B, pp. 1043-1171), Elsevier.

Ahmad, N., Moulton, B., Richardson, J.D., \& van de Ven, P. (2018). The Challenges of Globalization in the Measurement of National Accounts. NBER/Chicago: University of Chicago Press.

Amiti, Mary, Stephen J. Redding, and David E. Weinstein. 2019. "The Impact of the 2018 Tariffs on Prices and Welfare." Journal of Economic Perspectives, 33 (4): 187210.

Baldwin, R. (2006). Globalisation: The Great Unbundling(s). Economic Council of Finland, Prime Minister's Office, September 2006.

Baldwin, R. (2017). Factory-free Europe? A Two Unbundlings Perspective on Europe's Twentieth century Manufacturing Miracle and Twenty-first-century Manufacturing Malaise. Chapter in The Factory-Free Economy: Outsourcing, Servitization, and the Future of Industry. Fontagné, L and Harrison, A., eds. Oxford University Press Scholarship Online.

Baldwin, R. \& Robert-Nicoud, F. (2014). Trade-in-goods and trade-in-tasks: An integrating framework, Journal of International Economics, Volume 92, Issue 1, pp. 5162. 
Bayard, K., Byrne, D., \& Smith, D. (2015). The Scope of U.S. "Factoryless Manufacturing.” In S. Houseman \& M. Mandel (Eds.), Measuring Globalization: Better Trade Statistics for Better Policy - Volume 2. Factoryless Manufacturing, Global Supply Chains, and Trade in Intangibles and Data (pp. 81-120). Kalamazoo, MI: W.E.: Upjohn Institute for Employment Research.

BEIS (2018), Industrial Strategy: Building a Britain Fit for the Future, https://assets.publishing.service.gov.uk/government/uploads/system/uploads/attachment _data/file/664563/industrial-strategy-white-paper-web-ready-version.pdf

Bernard, A. B., \& Fort, T. C. (2013). Factoryless Goods Producers in the US, (NBER Working Paper Series No. 19396). Cambridge, MA.

Bernard, A. B., \& Fort, T. C. (2015). Factoryless Goods Producing Firms. American Economic Review: Papers \& Proceedings, 105(5), pp. 518-523.

Bernard, A. B., \& Fort, T. C. (2017). Factoryless Goods Producers in the USA. In L. Fontagne \& A. Harrison (Eds.), The Factory-Free Economy: Outsourcing, Servitization, and the Future of Industry (pp. 45-66). Oxford: Oxford University Press.

Bishop, A. and Mateos-Garcia, J. (2019). Exploring the Link Between Economic Complexity and Emergent Economic Activities, National Institute Economic Review, 249: pp. 47-58. 
Bryson, J., Clark, J. and Mulhall, R. (2013). The competitiveness and evolving geography of British manufacturing: where is manufacturing tied locally and how might this change? Future of Manufacturing Project: Evidence Paper 3. Government Office for Science, October 2013.

Coyle, D. \& Nguyen, D (2018). Cloud Computing and National Accounting. ESCoE Discussion Paper 2018-19, December 2019.

Crozet, M. \& Milet, E. (2017) Should everybody be in services? The effect of servitization on manufacturing firm performance. Journal of Economics \& Management Strategy, 26(4), pp. 820-841.

Desrosières, Alain (1993), La Politique des Grands Nombres, Histoire de la raison statistique, Paris: La Decouverte.

Doherty, M. (2017). Reflecting Factoryless Goods Production in the U.S. Statistical System. In Susan N. Houseman and Michael Mandel (Eds.), Measuring Globalization: Better Trade Statistics for Better Policy (Vol. 2, pp. 13-44). Kalamazoo, MI: W.E.: Upjohn Institute for Employment Research.

Donaghu, M.T. and Barff, R. (1990). 'Nike just did it: international subcontracting and flexibility in athletic footwear production.' Regional Studies, 24(6): 537-552. 
Economic Classification Policy Committee (ECPC). (2010). Recommendation for Classification of Outsourcing in North American Industry Classification System (NAICS) Revisions for 2012. Washington, DC.

Gereffi, G., Humphrey, J., \& Sturgeon, T. 2005. The governance of global value chains. Review of International Political Economy, 12(1): 78-104.

Hauge, J. \& O’Sullivan, E., (2019). Inside the Black Box of Manufacturing: Conceptualising and Counting Manufacturing in the Economy, University of Cambridge Institute for Manufacturing, Department of Engineering.

Houseman, S. N. and Mandel, M., (2015). Measuring Globalization: Better Trade Statistics for Better Policy. Kalamazoo, MI: W.E. Upjohn Institute for Employment Research.

Kamal, F (2018). A portrait of US factoryless goods producers, NBER working paper 25193, October 2018.

Kamal, F., Moulton, B. R., \& Ribarsky, J., (2015). Measuring "Factoryless" Manufacturing: Evidence from U.S. Surveys. In Susan N. Houseman and Michael Mandel (Eds.), Measuring Globalization: Better Trade Statistics for Better Policy (Vol. 2, pp. 45-80). Kalamazoo, MI: W.E.: Upjohn Institute for Employment Research.

Kinne, J \& Lenz, D, (2019). Predicting Innovative Firms using Web Mining and Deep Learning, ZEW Discussion Paper 19-001, January 2019. 
Langlois, Richard N. (2003). The vanishing hand: the changing dynamics of industrial capitalism, Industrial and Corporate Change, Volume 12, Issue 2, April 2003, Pages 351-385, https://doi.org/10.1093/icc/12.2.351

Levinson, M. (2017). 'What Is Manufacturing? Why Does the Definition Matter?' Cornell University ILR School, 2-6-2017

Linsi, Lukas \& Daniel K. Mügge (2019) Globalization and the growing defects of international economic statistics, Review of International Political Economy, 26:3, 361383

Mann, Michael (1997) Has globalization ended the rise and rise of the nation-state?, Review of International Political Economy, 4:3, 472-496

Mateos-Garcia, J., Stathoulopoloulos, K., Thomas, N., (2018). The Immersive Economy in the UK, NESTA https://media.nesta.org.uk/documents/Immersive_Technologies_PDF_lowres.pdf.

McKinsey Global Institute (2019). Globalization in Transition: The Future of Trade and Value Chains. McKinsey \& Company, January 2019.

Maurer, S (2017), Self-Governance in Science: Community Based Strategies for Managing Dangerous Knowledge, Cambridge University Press. 
Morikawa, M. (2016A). Factoryless goods producers in Japan. Japan and the World Economy, 40, pp. 9-15.

Office for National Statistics (2018). International trade in services, UK: 2016. ONS Statistical bulletin.

ONS (2019a). International trade in services, UK: 2017. Statistical Bulletin, Office for National Statistics, $31^{\text {st }}$ January 2019.

ONS (2019b). Understanding multinational enterprises: insights from the International Business Unit and foreign direct investment statistics, https://www.ons.gov.uk/economy/nationalaccounts/uksectoraccounts/compendium/econ omicreview/january2019/understandingmultinationalenterprisesinsightsfromtheinternati onalbusinessunitandforeigndirectinvestmentstatistics

Pabst A. (2020) Is Global Governance Unravelling? The Revolt Against Liberal Globalisation. In: Grigoryev L., Pabst A. (eds) Global Governance in Transformation. Springer

Penrose, E., (1959, 1995). The Theory of the Growth of the Firm, Oxford: Oxford University Press.

Pisano, Gary P. (2017). Toward a prescriptive theory of dynamic capabilities: connecting strategic choice, learning, and competition, Industrial and Corporate Change, Volume 26, Issue 5, October, pp. 747-762. 
Quinn, J.B. and Hilmer, F.G., (1994). Strategic Outsourcing. Sloan Management Review, 35(4), pp. 43-55.

Scott, James C, (1998) Seeing Like A State: How Certain Schemes to Improve the Human Condition Have Failed, Yale University Press.

Srai, J.S., Kumar, M. and Graham, G., (2016). 'Distributed Manufacturing: scope, challenges and Opportunities', International Journal of Production Research 54 (23), pp. 6917-6935.

Strange, R. \& Humphrey, J. (2019). 'What lies between market and hierarchy? Insights from internalization theory and global value chain theory.' Journal of International Business Studies, 50(8): 1401-1413.

Tassey, G. (2014). Competing in Advanced Manufacturing: The Need for Improved Growth Models and Policies, Journal of Economic Perspectives, 28 (1), pp. 27-48.

Teece, D. J., Pisano, G. and Shuen, A. (1997), Dynamic capabilities and strategic management. Strategic Management Journal, 18, pp. 509-533.

Timmer, M.P., Erumban, A.A., Los, B., Stehrer, R. \& de Vries G.J. (2014). 'Slicing up global value chains.' Journal of Economic Perspectives, 28(2): 99-118.

UNCTAD. (2011). World investment report 2011: Nonequity modes of international production and development. New York, Geneva: United Nations. 
UNECE. (2015). Guide to Measuring Global Production. New York \& Geneva.

Winch, G.M. (2003). How innovative is construction? Comparing aggregated data on construction innovation and other sectors - a case of apples and pears, Construction Management and Economics, 21:6, pp. 651-654. 
Table 1: Characteristics included in definitions of FGPs

Table 2. Estimates of impact of potential reclassification of factoryless manufacturers, US, Japan.

Table 3. Sector distribution of firms with a base in the UK that use or provide Contract Manufacturing Services. N=498. Source: Glass.AI, June 2019.

Table 4. . Sector distribution of firms with a base in the US that use or provide Contract Manufacturing Services. N=2,534. Source: Glass.AI, June 2019.

Table 5. UK trade in services, selected products. Source: International Trade in Services Survey, ONS January 2019.

Figure 1. 'Let us act as your factory'. Contract manufacturing advertising by John Wishart Machine Works, Chicago. Source: Popular Mechanics Vol.7(5), p. 570, May 1905.

Figure 2. Value chain choices in manufacturing Source: authors' own

Figure 3: Schematic representation of an FGP with an overseas--based contract manufacturer Source: authors' own 
Table 1

\begin{tabular}{|l|l|}
\hline Key characteristics & Included in definitions? \\
\hline $\begin{array}{l}\text { Owns and provides intellectual property and product } \\
\text { design specifications }\end{array}$ & Always \\
\hline Owns and provides necessary inputs & Some definitions \\
\hline Is owner and seller of final product & Always \\
\hline Pays a pre-defined price for final product & Some definitions \\
\hline Does not own production facilities at home / abroad & Most definitions \\
\hline Is not directly involved in transformation process & Always \\
\hline
\end{tabular}

Table 2

\begin{tabular}{|l|l|l|}
\hline Impact of potential reclassification & Country & Study \\
\hline Manufacturing employment underestimated by & United States & Bernard \& Fort (2017) \\
\hline $\mathbf{3 - 1 4 \%}$ in $\mathbf{2 0 0 7}$ & & \\
\hline Manufacturing value-added underestimated by & Unites States & Bayard, Byrne \& Smith (2015) \\
\hline $\mathbf{5 - 2 0 \%}$ in $\mathbf{2 0 0 7}$ & & Morikawa (2016) \\
\hline Number of manufacturing establishments & Japan & \\
\hline underestimated by 3-18\% in $\mathbf{2 0 1 3}$ & & \\
\hline
\end{tabular}

Table 3:

\begin{tabular}{|c|c|c|}
\hline & Sector & Share \\
\hline 1 & Chemicals & $18 \%$ \\
\hline 2 & Life Sciences \& Pharmaceuticals & $18 \%$ \\
\hline 3 & Biotechnology & $15 \%$ \\
\hline 4 & Electrical and & $13 \%$ \\
\hline
\end{tabular}




\begin{tabular}{|rlc|}
\hline \multicolumn{3}{|l|}{ Manufacturing } \\
\hline $\mathbf{5}$ & Mechanical \& Industrial & $9 \%$ \\
& Engineering & \\
\hline $\mathbf{6}$ & Medical Devices & $7 \%$ \\
\hline $\mathbf{7}$ & Cosmetics \& Toiletries & $3 \%$ \\
\hline $\mathbf{8}$ & Machinery & $3 \%$ \\
\hline $\mathbf{9}$ & Textiles & $3 \%$ \\
\hline $\mathbf{1 0}$ & Plastics & $2 \%$ \\
\hline $\mathbf{1 1}$ & Venture Capital \& Private Equity & $2 \%$ \\
\hline $\mathbf{1 2}$ & Outsourcing and Offshoring \\
\hline $\mathbf{1 3}$ & Logistics \& Supply Chain & $1 \%$ \\
\hline $\mathbf{1 4}$ & Packaging \& Print & $1 \%$ \\
\hline $\mathbf{1 5}$ & Food \& Beverages & $1 \%$ \\
\hline
\end{tabular}

Table 4 :

\begin{tabular}{|llc|}
\hline \multicolumn{2}{|l|}{ Sector } & Share \\
\hline $\mathbf{1}$ & Electrical \& Electronic & $14 \%$ \\
& Manufacturing & \\
\hline $\mathbf{2}$ & Life Sciences \& Pharmaceuticals & $11 \%$ \\
\hline $\mathbf{3}$ & Plastics & $10 \%$ \\
\hline $\mathbf{4}$ & Medical Devices & $9 \%$ \\
\hline $\mathbf{5}$ & Chemicals & $8 \%$ \\
\hline $\mathbf{6}$ & Machinery & $7 \%$ \\
\hline $\mathbf{7}$ & Semiconductors \& Electronic & $7 \%$ \\
\hline
\end{tabular}




\begin{tabular}{|clc|}
\hline \multicolumn{2}{|l|}{ Systems } \\
\hline $\mathbf{8}$ & Biotechnology & $6 \%$ \\
\hline $\mathbf{9}$ & Mechanical \& Industrial Engineering & $6 \%$ \\
\hline $\mathbf{1 0}$ & Industrial Automation & $3 \%$ \\
\hline $\mathbf{1 1}$ & Outsourcing \& Offshoring & $3 \%$ \\
\hline $\mathbf{1 2}$ & Aviation, Aerospace \& Defence & $3 \%$ \\
\hline $\mathbf{1 3}$ & Cosmetics \& Toiletries & $2 \%$ \\
\hline $\mathbf{1 4}$ & Mining and Minerals & $2 \%$ \\
\hline $\mathbf{1 5}$ & Logistics \& Supply Chain \\
\hline $\mathbf{1 6}$ & Food \& Beverages & $1 \%$ \\
\hline $\mathbf{1 7}$ & Investment Banking \& Advisory & $1 \%$ \\
\hline $\mathbf{1 8}$ & Computer Hardware & $1 \%$ \\
\hline $\mathbf{1 9}$ & Packing \& Print & $1 \%$ \\
\hline & Venture Capital \& Private Equity \\
\hline & & $1 \%$ \\
\hline
\end{tabular}

Table 5:

\begin{tabular}{|c|c|c|c|c|c|c|}
\hline & 2013 & 2014 & 2015 & 2016 & 2017 & 2018 \\
\hline & \multicolumn{3}{|c|}{ Exports (£ million) } & & & \\
\hline Merchanting & 3585 & 1395 & 2241 & 2691 & 7223 & 10330 \\
\hline $\begin{array}{l}\text { Manufacturing } \\
\text { services }\end{array}$ & 2555 & 2103 & 2350 & 2735 & 3518 & 2739 \\
\hline \multirow[t]{2}{*}{ Charges for IP } & 1446 & 1561 & 1737 & 1455 & 1985 & 2833 \\
\hline & \multicolumn{3}{|c|}{ Imports ( $£$ million) } & & & \\
\hline
\end{tabular}




\begin{tabular}{|l|l|l|l|l|l|l|}
\hline Merchanting & 437 & 1099 & 372 & 345 & 304 & 401 \\
\hline $\begin{array}{l}\text { Manufacturing } \\
\text { services }\end{array}$ & 760 & 581 & 627 & 601 & 925 & 1256 \\
\hline Charges for IP & 669 & 586 & 686 & 919 & 1310 & 2780 \\
\hline
\end{tabular}


Figures

Figure 1:

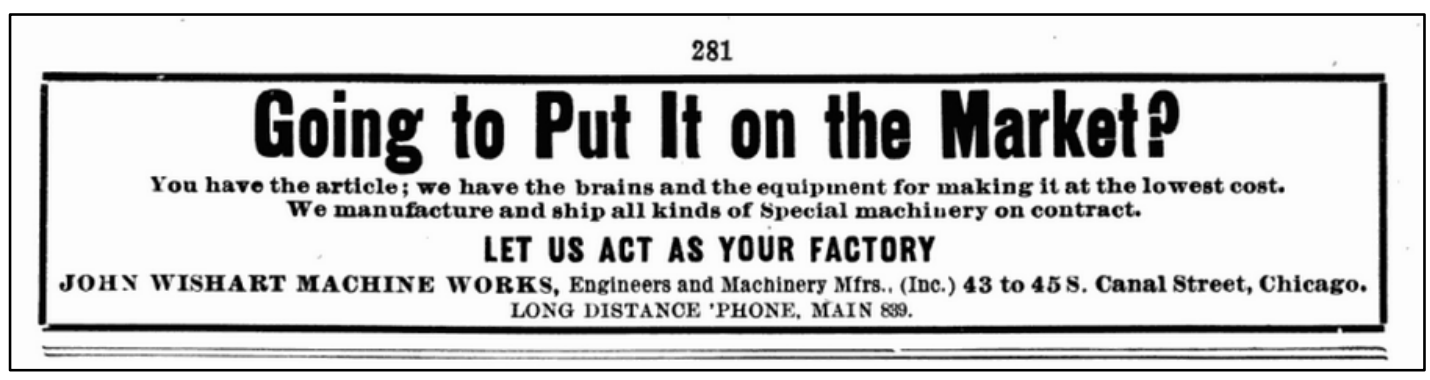

Figure 2:

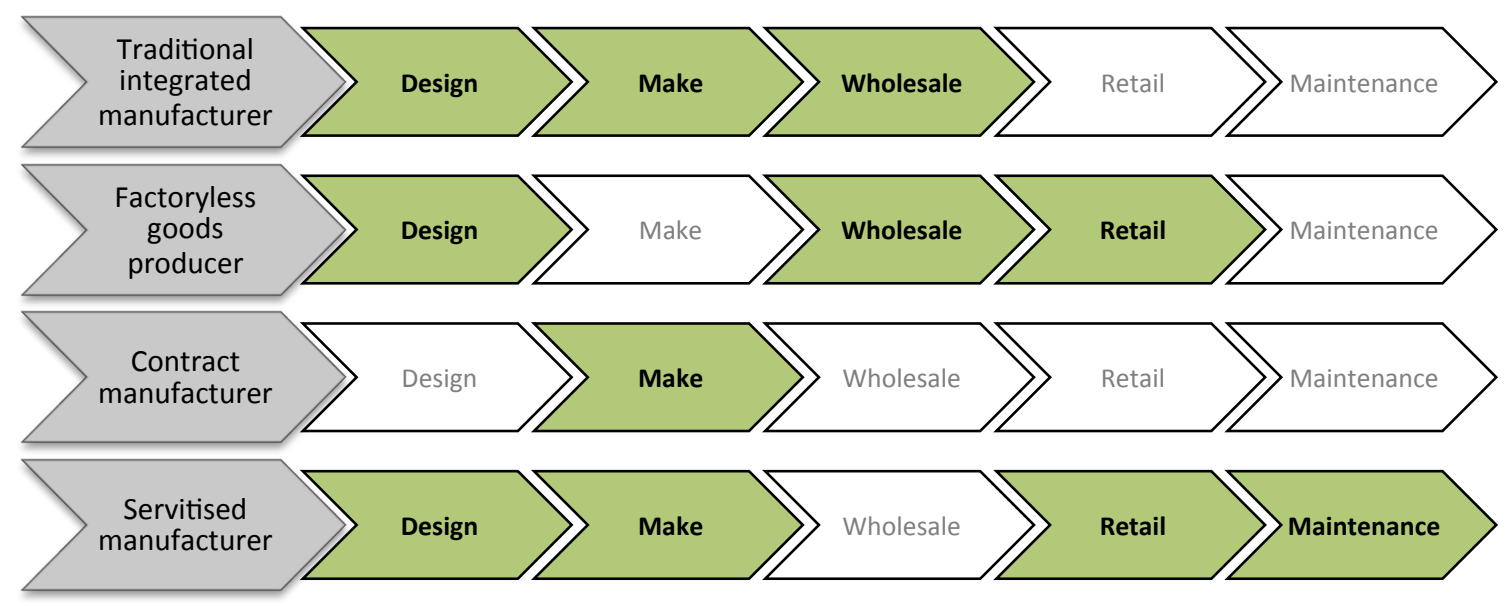

Figure 3: 


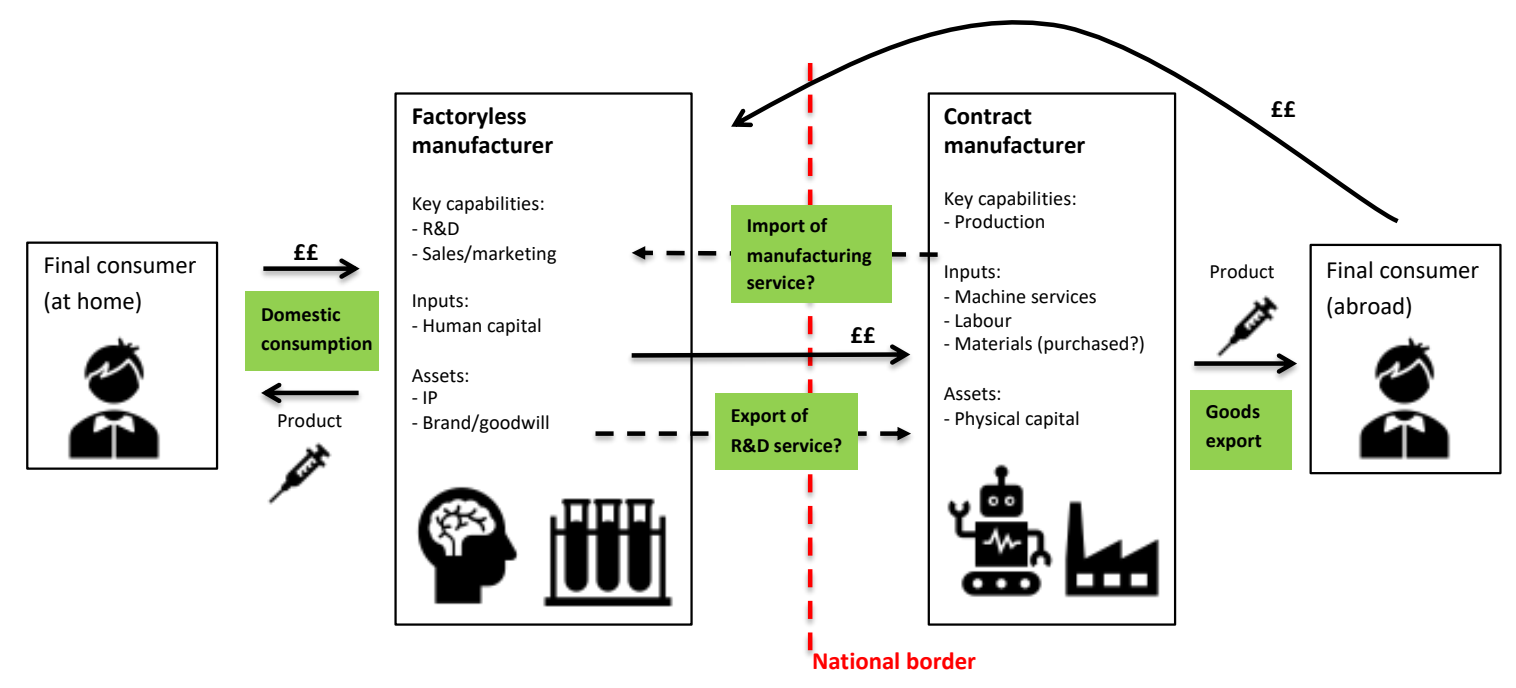

